\title{
On the identity of the new family Pycnanthaceae Ravenna
}

\section{Sobre la identidad de la nueva familia Pycnanthaceae Ravenna}

\author{
Marcela V. Nicola \\ Instituto de Botánica Darwinion (IBODA), Labardén 200, Casilla de Correo 22, B1642HYD, San Isidro, Buenos Aires, \\ Argentina. \\ mnicola@darwin.edu.ar
}

\begin{abstract}
The taxonomic position of a new family of flowering plants recently described, Pycnanthaceae Ravenna, is here discussed; as a result of comparison of type material, this new taxon is placed in the synonymy of the genus Malaxis within the Orchidaceae. A list of species of Malaxis growing in Argentina is provided, as well as a key to differentiate them.
\end{abstract}

KeYwords: Argentina, Malaxis, Orchidaceae, Pycnantha, taxonomy.

\section{RESUMEN}

En esta contribución se analiza la posición taxonómica de la familia Pycnanthaceae Ravenna; como resultado del análisis del material tipo de Pycnantha orchioides, este taxón es considerado un sinónimo del género Malaxis. Se incluye una lista de las especies de Malaxis que crecen en la Argentina, como así también una clave para distinguirlas.

Palabras clave: Argentina, Malaxis, Orchidaceae, Pycnantha, taxonomía.

Ravenna (2011) established the new family Pycnanthaceae with a single genus and species, Pycnantha orchioides. These new taxa were based on a specimen collected in Lagunas de Yala, Jujuy, Argentina, by A.L. Cabrera and H. Fabris in 1966; the holotype is deposited in Herbario Gaspar Xuárez, Facultad de Agronomía of the University of Buenos Aires (BAA), while an isotype is deposited in the herbarium of Museo de La Plata (LP). When establishing the Pycnanthaceae, Ravenna (2011) ambiguously stressed that the family is distinguished by a "group of peculiar characters of the plant", without defining these characters, and also by the "impossibility to assign it to a known family". Ravenna mentioned that the new family is in an intermediate position between the Convallariaceae and Hyacinthaceae, on one extreme, and family Orchidaceae in the other. Both the description of the family, genus, and species are inaccurate; also, no figures, keys or other elements are included with the original diagnosis.

The purpose of this contribution is to evaluate the taxonomic status of these new entities, and their possible relationship with other families of Monocots. Therefore, the herbarium material of the cited specimens of Pycnantha orchioides were examined, together with pertinent literature, and compared them with taxa of the putative related families, in particular with Orchidaceae and species of the genus Malaxis.

After analyzing the holotype of $P$. orchioides (Cabrera \& Fabris 17413, BAA; Fig. 1), and also another specimen identified by Ravenna as this species (Cabrera et al. 27589, BAA, SI), it became clear that both specimens belong to the genus Malaxis (Orchidaceae) because of their umbellate, pluri-flowered, terminal inflorescence, with yellow or green small flowers falling together with the peduncles, not articulate with the ovaries, labellum without a noticeable spur, short and straight column without a conspicuous base, pollinia without caudicle or retinacle, pseudobulbs bifoliate, and leaves thin. These characters agree with the delimitation of Malaxis as proposed by Williams (1939) and Johnson (2001). Since most taxa of the Orchidaceae have a well developed column, it is most likely that Ravenna (2011) failed to associate the specimens studied to this family due to the presence of a short column, a feature present in species of Malaxis. 


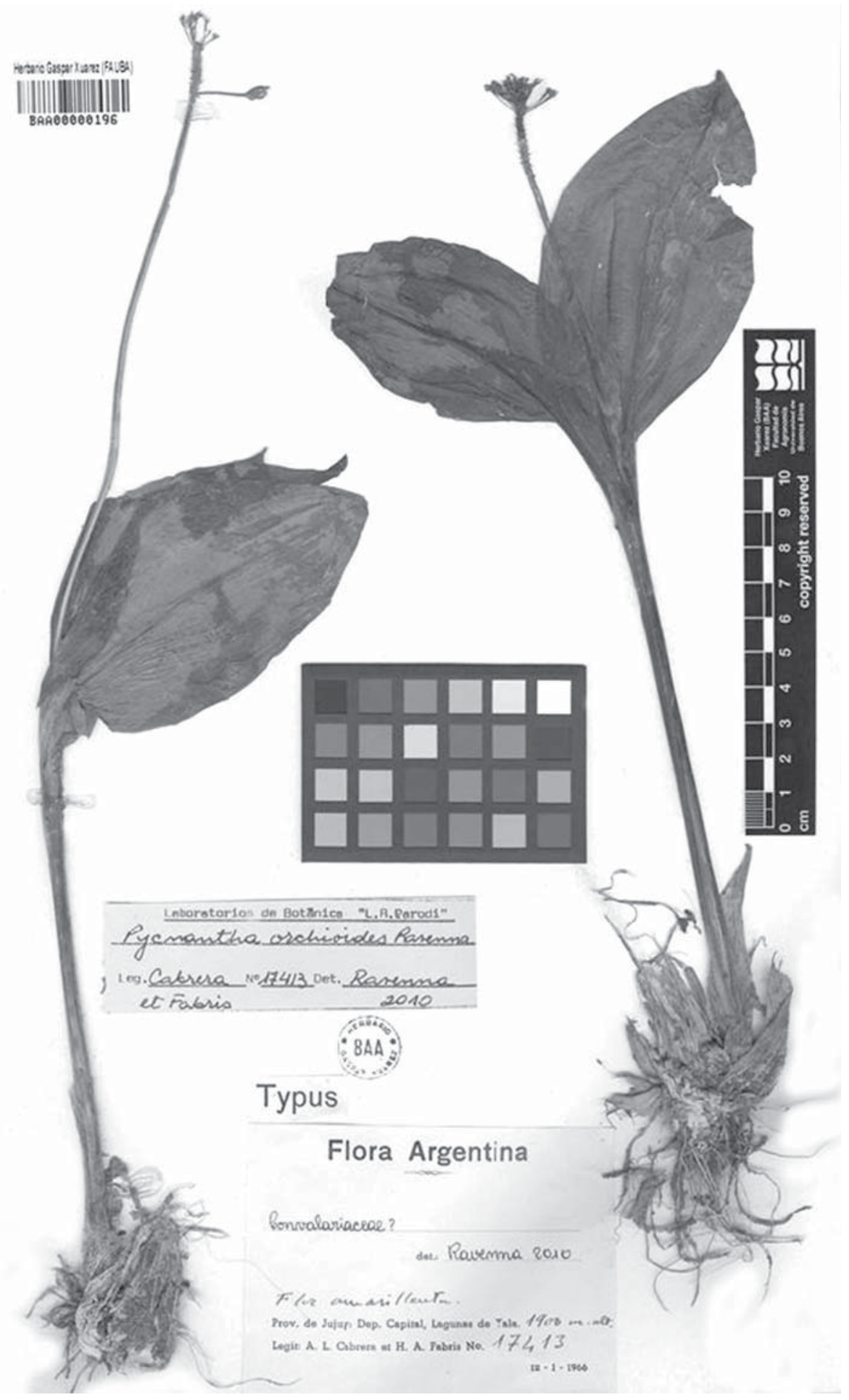

FIgURE 1. Holotype of Pycnantha orchioides Ravenna.

FIgURA 1. Holotipo de Pycnantha orchioides Ravenna. 
Malaxis is a cosmopolitan genus with nearly 300 species distributed in tropical and temperate regions of the World (Stevens et al. 2001). The genus includes four species in Argentina, of which three, M. excavata (Lindl.) Kuntze, M. hieronymi (Cogn.) L.O. Williams, M. padillana L.O. Williams, are restricted to humid areas of the northwest while $M$. parthoni C. Morren is also present in northeastern Argentina (Schinini et al. 2008). Species of Malaxis can be distinguished by apical and basal characteristics of the labellum. In the examined type material of Pycnantha orchioides, the labellum is ovate and exhibits retrorse and sagittate auricles at its base, while the apex is tridentate with the medium tooth longer than the lateral ones, characteristics stressed by Lindley (1838) when describing Microstylis excavata. Therefore, there is no doubt that these materials can be assigned to Malaxis excavata (Lindl.) Kuntze (Fig. 2), a terrestrial herb widely distributed from Mexico to Argentina (Williams 1938), where it is found in the provinces of Jujuy, Salta, and Tucumán. The key below, based on Williams (1939), will aid in identifying the species of Malaxis recognize for Argentina. It is followed by formal presentation of the names by the new taxonomic treatment.

\section{Preliminary Key OF THE SPECIES OF MaLAXIS OF ARgentina}

1. Labellum with the base auriculate

2. Labellum with the apex tridentate, with the medium tooth longer than the lateral ones ....................... excavata

2'. Labellum with the apex entire. M. parthoni

1 '. Labellum with the base not auriculate

3. Labellum with the apex trilobate M. padillana

3 '. Labellum with the apex entire. M. hieronymi

\section{TAXONOMIC TREATMENT}

Orchidaceae Juss., Gen. Pl.: 64. 1789.

Pycnanthaceae Ravenna, Onira, 12(6): 29. 2011. Type: Pycnantha Ravenna

Malaxis Sw., Nov. Gen. Spec. Plant.: 119. 1788. Pycnantha Ravenna, Onira 12(6): 30. 2011. Type species: Pycnantha orchioides Ravenna

Malaxis excavata (Lindl.) Kuntze, Revis. Gen. Pl. 2: 673. 1891. Microstylis excavata Lindl., Edward's Bot. Reg. 24: Misc. 51. 1838. TYPE: Mexico. Without locality, Barker s.n. (holotype, K; isotype and drawing of a spikelet, $\mathrm{GH}$ !). Pycnantha orchioides Ravenna, Onira 12(6): 31. 2011.

\section{AdDitionAl SPECIMENS EXAMINED}

Malaxis excavata (Lindl.) Kuntze

ARGENTINA, Prov. Jujuy, Dpto. Dr. M. Belgrano, Lagunas de Yala, 2500 a.s.1., 16-II-1987, Nicora 8723 (SI). Dpto. Ledesma, Parque Nacional Calilegua, 1900 a.s.l., 03-II1999, Johnson 821 (SI). Prov. Salta, Dpto. Santa Victoria, Arroyo Huaico Grande, 20-XI-2001, Morrone 3850 (SI). Prov. Tucumán, Dpto. Chicligasta, Estancia Las Pavas, 1000 a.s.1., 08-III-1924, Venturi 2951 (SI).

Malaxis hieronymi (Cogn.) L.O. Williams ARGENTINA, Prov. Catamarca, Dpto. Andalgalá, without locality, 20-XII-1916, Jörgensen 1479 (SI). Prov. Jujuy,
Dpto. Dr. Manuel Belgrano, Quebrada de León, 20-I2012, Zanotti 168 (SI). Dpto. Valle Grande, de Santa Ana a Cortaderas, 13-I-2012, Zuloaga et al. 13470 (SI). Prov. Salta, Dpto. Santa Victoria, Arroyo Peña Negra, 3360 a.s.l. 15-II-2009, Zuloaga et al. 10763 (SI).

Malaxis padillana L.O. Williams

ARGENTINA, Prov. Salta, Dpto. Cachi, Cuesta del Obispo, 2807 a.s.1., 22-I-2002, Solís Neffa et al. 890 (SI). Prov. Tucumán, Dpto. Chicligasta, Estancia Las Pavas, 12001800 a.s.1., 10-XII-1925, Venturi 4059 (SI).

Malaxis parthoni C. Morren

ARGENTINA, Prov. Jujuy, Dpto. Ledesma, Arroyo Aguas Negras, 24-XII-1993, Johnson 428 (SI). Prov. Misiones, Dpto. Gral. M. Belgrano, Reserva de Vida Silvestre Uruguaí, 400 a.s.1., 20-IV-2002, Johnson 1004 (SI).

\section{ACKNOWLEDGMENTS}

To the curators of BAA, Roberto Tortosa and Adriana Bártoli, for their kindness and disposition to have access to the herbarium material of Pycnantha and Malaxis; also to Norma Deginani, curator of SI, for facilitating material of Malaxis from the Darwinion herbarium. To Liliana Mallo, Raúl Pozner and Mabel Suescún for help with Figure 2, and Fernando Zuloaga and two anonymous reviewers for providing valuable comments on the final version of this manuscript. 


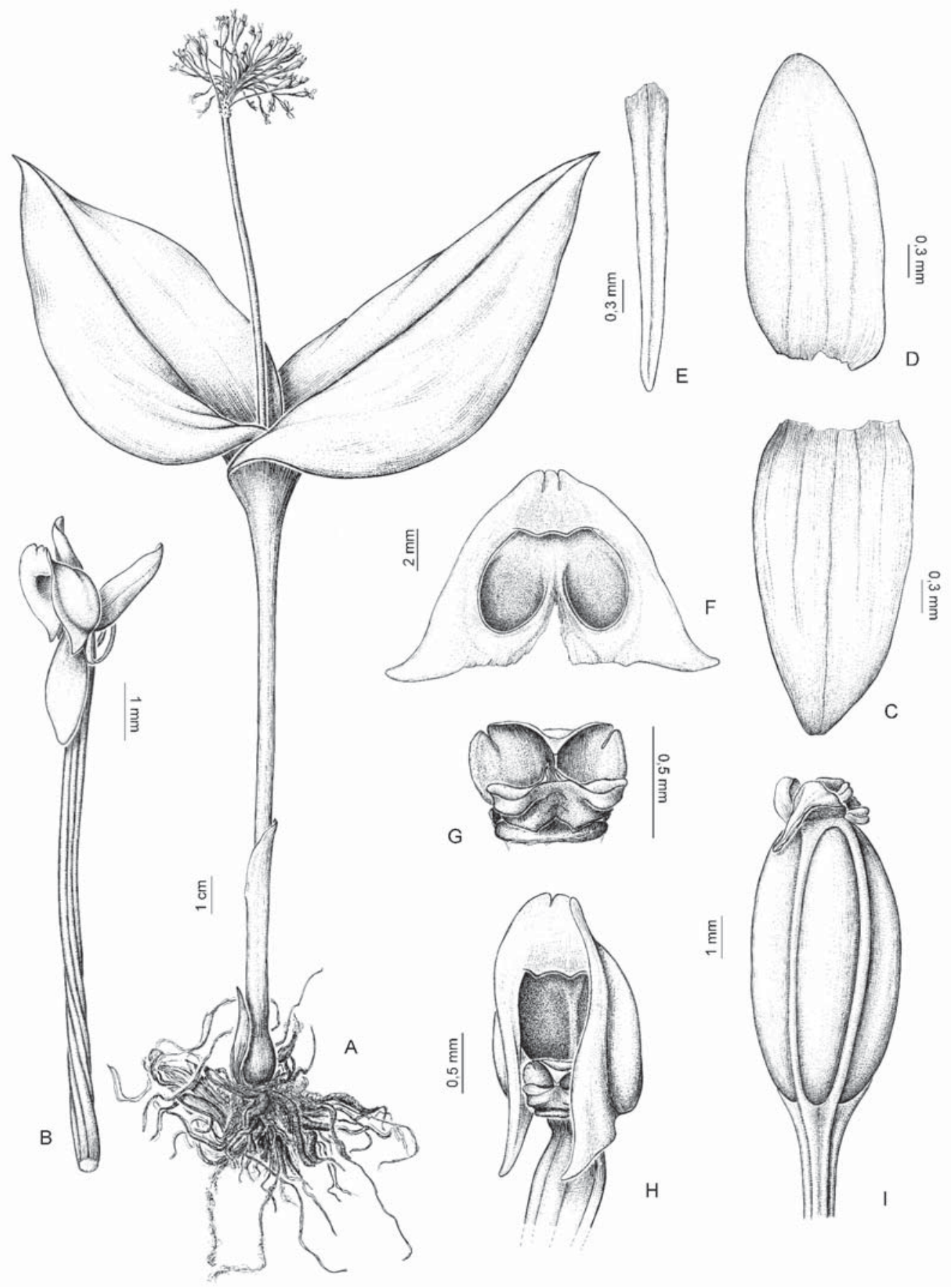

Figure 2. Malaxis excavata (Lindl.) Kuntze. A) Plant. B) Flower with peduncle. C) Dorsal sepal D) Lateral sepal. E) Petal. F) Labellum. G) Column H) Disposition of the labellum over the column and the peduncle. I) Fruit. "A" to "H" based on A. L. Cabrera et al. 27589, and "I" based on A. Krapovickas et A. Schinini 30231.

Figura 2. Malaxis excavata (Lindl.) Kuntze. A) Planta. B) Flor con pedúnculo. C) Sépalo dorsal. D) Sépalo lateral. E) Pétalo. F) Labelo. G) Columna. H) Disposición del labelo sobre la columna y el pedúnculo. I) Fruto. "A" a "H" basado en A. L. Cabrera et al. 27589, e "I" basado en A. Krapovickas et A. Schinini 30231. 


\section{REFERENCES}

Johnson, A.E. 2001. Las orquídeas del Parque Nacional Iguazú. Literature of Latin America (L.O.L.A.), Buenos Aires, Argentina. $282 \mathrm{pp}$.

LindLEY, J. 1838. Ornamental flower-garden and shrubbery. Edwards's Botanical Register 24: Miscellaneous 51.

Ravenna, P. 2011. Pycnantha, a new genus of a new family of monocotyledons, including a new species from Argentina. Onira 12(6): 29-32.

Schinini, A., J. Waechter, P. Izaguirre \& C. Lehnebach. 2008. Orchidaceae. Pp. 540. En: F.O. Zuloaga, O. Morrone, M.J.
Belgrano, C. Marticorena \& E. Marchesi (eds.), Catálogo de las plantas vasculares del Cono Sur (Argentina, sur de Brasil, Chile, Paraguay y Uruguay). Monographs in Systematic Botany from the Missouri Botanical Garden 107: 1-983.

Stevens, W.D., A. Pool \& O.M. Montiel. 2001. Flora de Nicaragua. Monographs in Systematic Botany from the Missouri Botanical Garden 81: 1735-1739.

Williams, L.O. 1938. The nomenclatorial status of Malaxis excavata. Botanical Museum Leaflets 6: 75-76.

WiLliams, L.O. 1939. Las orquidáceas del noroeste argentino. Lilloa 4: 337-375.

Recibido: 04.04.12

Aceptado: 05.06.12 